\title{
Electroencephalographic abnormalities in COVID-19-related encephalopathies: A systematic review
}

\author{
Jie Pan MD, PhD, Shazma Khan BSA, Smathorn Thakolwiboon MD, Dargelis Chi MD
}

\begin{abstract}
Background: Acute encephalopathy is a common neurological manifestation in coronavirus disease 2019 (COVID-19) patients and presents with confusion, delirium, orpoor responsiveness. Non-convulsive status epilepticus (NCSE) is an important differential diagnosis in this situation. The electroencephalography (EEG) patterns in COVID-19 patients remain largely unknown.

Method: A literature search was conducted on MEDLINE, EMBASE, and Cochrane database. Eligibility criteria included case series and case reports of COVID-19 patients with neurological complication who underwent EEG. Two authors screened all resulting studies and extracted the data independently.

Results: Four retrospective case control studies and eleven case reports were identified. Background diffuse slow activity were seen in most of the COVID-19 patients. Other EEG patterns reported included status epilepticus, focal slow activity, rhythmic periodic discharges, and interictal epileptiform discharges. Imaging and CSF studies were available in only a few patients.

Conclusions: Acute encephalopathy is common in the context of COVID-19. There is no specific EEG pattern found in these patients.
\end{abstract}

Keywords: COVID-19, coronavirus, SAR-CoV-2, electroencephalogram, EEG

\section{INTRODUCTION}

The global pandemic of severe respiratory syndrome coronavirus 2 (SARS-CoV-2), known as COVID19 , presents a substantial public health challenge. The virus not only infects the respiratory system but can disseminate into other tissues and cause multi-organ failure. ${ }^{1}$ Accumulating evidence has demonstrated that neurological symptoms can develop in COVID-19 patients. ${ }^{2,3}$ Acute encephalopathy with impaired consciousness is a common neurological phenomenon in these patients, which may stem from several pathophysiological mechanisms. Electroencephalography (EEG) is often performed in patients with an altered mental status and to rule out subclinical seizure in

Corresponding author: Jie Pan

Contact Information: Jie.Pan@ttuhsc.edu

DOI: 10.12746/swrccc.v8i35.741 hospitalized patients. The availability of EEG testing in COVID-19 patients has been limited due to the contagiousness of the virus, and information about EEG patterns in COVID-19 related encephalopathy is limited.

This study reviews and summarizes the literature on EEG studies performed in COVID-19 patients around the world. The purpose of this brief review is to better understand EEG patterns in COVID-19 related encephalopathy.

\section{Methods}

\section{LITERATURE SEARCH STRATEGY}

Two investigators (J.P. and S.T.) independently searched for published articles indexed in MEDLINE, EMBASE, and Cochrane databases from inception to July 6, 2020. The search strategy included the terms for EEG and coronavirus and is available in 
Supplementary Table 1. References of the included articles and the relevant links were also manually reviewed for additional eligible articles.

\section{SELECTION CRITERIA AND DATA EXTRACTION}

The inclusion criteria for the systematic review included case series or case reports of COVID-19 patients with encephalopathy who underwent EEG. Data extraction was independently performed by J.P. and S.K. using a standardized data collection form to collect the following information: demographic data, study design, neurological manifestation, neuroimaging findings, cerebrospinal fluid study, and EEG findings. Disagreements were resolved by consensus and with another author (S.T.) if needed.

\section{RESULTS}

The literature review process is shown in Figure 1. The initial systematic search identified 49 studies; five additional articles were identified through the reference review and personal library. After removal of duplicates, 40 articles were screened through titles and abstracts for potential relevance. Nineteen selected articles underwent full-text review. Finally, four retrospective case series (Table 1$)^{4-7}$ and 11 case reports were identified (Table 2 ). ${ }^{8-18}$

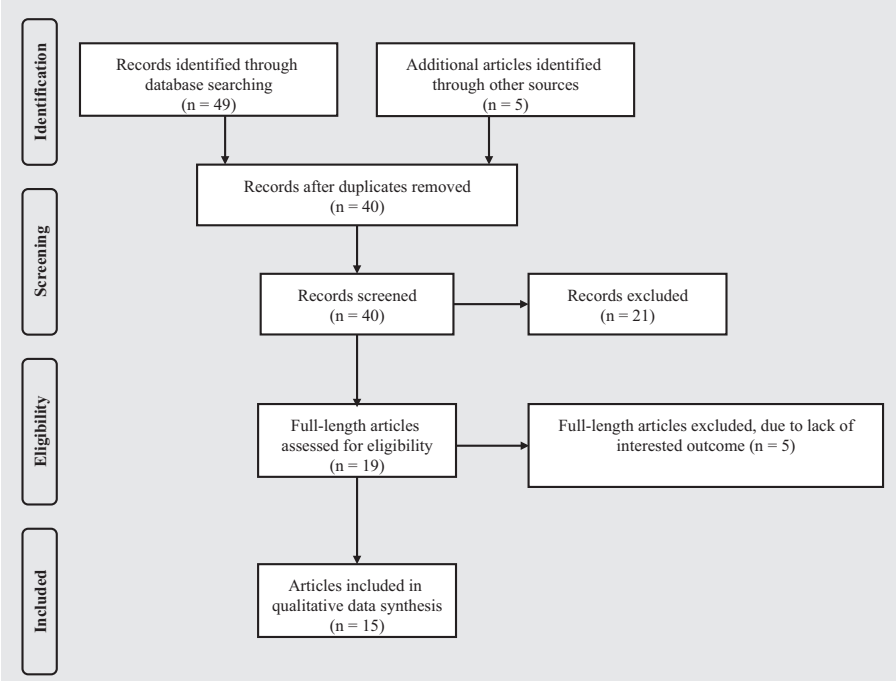

Figure 1. Flow diagram of literature search results, article screening, and article inclusion numbers.
The findings from the four case series are summarized in Table 1. In the 78 patients reported in these four studies, background diffuse slow activity was seen in 68 patients $(87.1 \%)$. Interictal epileptiform discharges were seen in 11 patients (14.1\%). Non-convulsive status epilepticus (NCSE) was seen in one patient (1.3\%), but it was unclear if this patient had a prior history of seizures. Focal slow activity was seen in 12 patients $(15.4 \%)$; seven of these patients have confirmed focal lesions, and five had inadequate information to identify an exact cause. Generalized periodic discharges were seen in eight patients $(10.2 \%)$; four of these patients had been intubated, and one was known to be not intubated. One of these patients had anoxic injury due to cardiac arrest, and one was on ECMO. Information regarding the other patients was imcomplete. Burstsuppression or isoelectric EEGs were seen in three patients $(3.8 \%)$ due to hypoxic brain injury.

There were 12 cases in 11 case report articles; 11 were adults and 1 was an infant (6 months) (Table 2). In the adult patients, background diffuse slow activity were reported in seven patients. Status epilepticus was reported in 5 patients: one patient had a known prior epileptogenic focal lesion, one had a known new focal lesion, and three had status epilepticus without a known focal lesion (one of the three patients did not have an MRI). Epileptiform discharges (but not status seizures) were seen in three patients; a known prior epileptogenic focal lesion was reported in one of the three patients.

\section{Discussion}

Neurological symptoms are becoming increasingly recognized in COVID-19 patients. An EEG is a common study used for evaluating altered mental status and seizures during routine clinical care. However, data show that the volume of EEG studies has decreased significantly during the pandemic to minimize unnecessary exposure for neurophysiology technicians. ${ }^{19}$ From studies used in this review, common neurological manifestations prompting EEG evaluation included new encephalopathy (confusion, delirium), poor responsiveness after stopping sedation, and suspicion for clinical or subclinical seizures.

In general, there is no specific EEG pattern in COVID19 related encephalopathy. Background abnormality of 
Table 1. Summary of EEG Findings from Case Series

\begin{tabular}{|c|c|c|c|c|c|c|c|}
\hline Author & Study type & Age & EEG type & $\begin{array}{l}\text { Neurological } \\
\text { symptoms }\end{array}$ & EEG pattern & Images & CSF study \\
\hline Scullen $^{7}$ & $\begin{array}{l}\begin{array}{l}\text { Retrospective } \\
\text { case series } \\
\text { study } \\
\mathrm{N}=12\end{array}\end{array}$ & $35-91$ & Not mentioned & $\begin{array}{l}\text { Encephalopathy } \\
\text { can not be } \\
\text { explained by } \\
\text { CT/MRI }\end{array}$ & $\begin{array}{l}\text { 11/12: diffuse slow (theta- } \\
\text { delta activity); 1/12: NCSE }\end{array}$ & $\begin{array}{l}\text { Done, but did not } \\
\text { mention the correlation } \\
\text { with EEG }\end{array}$ & Not done \\
\hline
\end{tabular}

Abbreviation: LOC: loss of consciousness; EEG: electroencephalography; PDR: posterior dominant rhythm; AP gradient: anterior-posterior gradient; IPH: intracranial parenchymal hemorrhage; PRES: posterior reversible encephalopathy; GPDs: generalized periodic discharges; LPDs: lateralized periodic discharges; NSCE: non-convulsive status epilepticus.

diffuse slow activity (theta-delta activity) and absence of posterior dominant rhythm (PDR) have been seen in a majority of patients. These EEG background patterns are nonspecific for encephalopathy caused by different etiologies, including hypoxic/hypercapnic encephalopathy, metabolic derangements, electrolytes disturbance, and inflammatory cascade following viral infection. ${ }^{20,21}$ All these can occur in COVID-19 patients. These EEG background patterns in COVID-19 related encephalopathy range from diffuse slow activity to burst-suppression to even isoelectric EEGs.

Generalized periodic discharge is an unique EEG pattern, suggesting diffuse brain dysfunction, but it remains challenging to differentiate from NCSE in certain clinical situations. ${ }^{22,23}$ This EEG pattern typically occurs in toxic-metabolic encephalopathy, such as hepatic and uremic encephalopathy, but can also occur in CNS viral infections, such as subacute sclerosing panencephalitis. ${ }^{24}$ Similar to other coronaviruses, COVID-19 can cause direct CNS invasion. ${ }^{25}$ However, lumbar punctures have been performed in very few patients during the COVID-19 pandemic. In addition, the value of a routine CSF panel without specific PCR study in the diagnosis of viral encephalitis is limited. Though there are case reports showing that COVID-19 has been detected in CSF PCR, ${ }^{12,26}$ most of the studies did not report positive results.

A focal EEG pattern in COVID-19 patients has also been reported, including focal slowing, lateralized periodic discharges, or focal epileptiform discharges. Usually, the existence of focal abnormalities should lead to imaging studies to screen for intracranial lesions. Unfortunately, MRIs of the brain are not widely available in COVID-19 patients. Emerging evidence showed that different etiologies are involved in COVID-19 related focal brain lesions; these include necrotic encephalitis, 
Table 2. Summary of Case Report of EEG in and COVID-19 Patients

\begin{tabular}{|c|c|c|c|c|c|c|}
\hline Author & $\begin{array}{l}\text { Age/ } \\
\text { Gender }\end{array}$ & $\begin{array}{l}\text { Neurological } \\
\text { symptoms }\end{array}$ & $\begin{array}{l}\text { History of } \\
\text { seizures }\end{array}$ & EEG pattern & Images & CSF Study \\
\hline Balloy $^{8}$ & $59 / \mathrm{M}$ & NSCE & No & $\begin{array}{l}\text { Epileptiform discharges } \\
\text { from bifrontal lobes }\end{array}$ & MRI normal & $\mathrm{Neg}$ \\
\hline $\begin{array}{l}\text { Bernard- } \\
\text { Valnet }^{9}\end{array}$ & $64 / \mathrm{F}$ & $\begin{array}{l}\text { Tonic-clinic } \\
\text { seizure }\end{array}$ & No & Focal status epilepticus & MRI: Neg & Neg \\
\hline $\begin{array}{l}\text { De } \\
\text { Stefano }^{10}\end{array}$ & $56 / \mathrm{F}$ & AMS & No & $\begin{array}{l}4 \mathrm{~Hz} \text { rhythms over } \\
\text { bilateral parasagittal } \\
\text { region }\end{array}$ & $\begin{array}{l}\text { MRI: diffuse } \\
\text { microbleed }\end{array}$ & $\begin{array}{l}\text { Increased } \\
\text { protein; PCR } \\
\text { neg }\end{array}$ \\
\hline Dugue $^{11}$ & $0.5 / \mathrm{M}$ & $\begin{array}{l}\text { An episode of } \\
\text { sustained upward } \\
\text { gaze with bolateral } \\
\text { leg stiffening } \\
\text { and decreased } \\
\text { response. }\end{array}$ & No & $\begin{array}{l}\text { Excess of temporal sharp } \\
\text { transients for age and } \\
\text { intermittent vertex delta } \\
\text { slowing with normal } \\
\text { sleep-wake cycling }\end{array}$ & MRI unremarkable & N/A \\
\hline Duong $^{12}$ & $41 / \mathrm{F}$ & $\begin{array}{l}\text { Lethargic, } \\
\text { meningeal } \\
\text { irritation }\end{array}$ & No & Diffuse slow & CTH: neg & $\begin{array}{l}\text { COVID PCR } \\
\text { Pos }\end{array}$ \\
\hline Filatov $^{13}$ & $74 / \mathrm{M}$ & Headache, AMS & No & $\begin{array}{l}\text { Left focal slow and sharp } \\
\text { wave from left temporal } \\
\text { lobe. }\end{array}$ & $\begin{array}{l}\text { CTH: remote stroke } \\
\text { with left temporal lobe } \\
\text { encephalomalacia }\end{array}$ & $\begin{array}{l}\text { Increased } \\
\text { protein; PCR } \\
\text { neg }\end{array}$ \\
\hline Flamand $^{14}$ & $80 / \mathrm{F}$ & $\begin{array}{l}\text { Focal motor } \\
\text { seizure }\end{array}$ & No & $\begin{array}{l}\text { Diffuse slow and } \\
\text { repetitive epileptiform } \\
\text { discharges from bifrontal }\end{array}$ & CTH: unremarkable & \\
\hline $\begin{array}{l}\text { Le } \\
\text { Guennec }\end{array}$ & $69 / \mathrm{M}$ & NCSE & No & $\begin{array}{l}\text { Focal status epilepticus } \\
\text { from right frontal lobe }\end{array}$ & $\begin{array}{l}\text { MRI: right frontal lobe } \\
\text { new lesion, resolved in } \\
30 \text { days }\end{array}$ & $\mathrm{Neg}$ \\
\hline Pilotto $^{16}$ & $50 / \mathrm{M}$ & $\begin{array}{l}\text { Progressive } \\
\text { irritability, } \\
\text { confusion, akinitic } \\
\text { mutism, suspected } \\
\text { for immune-related } \\
\text { encephalitis }\end{array}$ & No & $\begin{array}{l}\text { Diffuse slow (theta } \\
\text { activity) }\end{array}$ & MRI unremarkable & $\begin{array}{l}\text { Mild } \\
\text { lymphocytic } \\
\text { pleocytosis } \\
\text { and moderate } \\
\text { increasd CSF } \\
\text { protein; } \\
\text { CSF PCR neg }\end{array}$ \\
\hline $\begin{array}{l}\text { Somani, } \\
(\text { case1) })^{17}\end{array}$ & $49 / \mathrm{F}$ & Multiple seizure & No & $\begin{array}{l}\text { Epileptiform discharges } \\
\text { from midline and left } \\
\text { fronto-central region }\end{array}$ & MRI unremakable & $\mathrm{n} / \mathrm{a}$ \\
\hline $\begin{array}{l}\text { Somani } \\
(\text { case } 2)^{17}\end{array}$ & $73 / \mathrm{F}$ & $\begin{array}{l}\text { New onset } \\
\text { refractory } \\
\text { status epilepticus } \\
\text { (NORSE) }\end{array}$ & No & $\begin{array}{l}\text { Bilateral independent } \\
\text { periodic dhacharges } \\
\text { (BIPDs). }\end{array}$ & CTH unremarkable & $\mathrm{n} / \mathrm{a}$ \\
\hline Vollono $^{18}$ & $78 / \mathrm{F}$ & NCSE & $\begin{array}{l}\text { Focal seizure } \\
\text { due to prior HSV } \\
\text { encephalitis }\end{array}$ & $\begin{array}{l}\text { Focal status epilepticus } \\
\text { (same region, left fronto- } \\
\text { parietal) }\end{array}$ & $\begin{array}{l}\text { MRI: encephalomalacia } \\
\text { from left fronto-parietal }\end{array}$ & Not done \\
\hline
\end{tabular}

Abbreviation: NSCE: non-convulsive status epilepticus; AMS: altered mental status; HSV: herpes simplex virus; EEG: electroencephalography. 
immune-mediated encephalitis, and cerebrovascular events caused by vasculopathy and a hypercoagulable state. ${ }^{27}$ In a case report of a COVID-19 patient with acute encephalopathy, the EEG showed epileptiform discharges from the right frontal region. This EEG finding correlated with a new but temporary lesion in the right frontal lobe shown in an MRI; the CT of the head and the CSF study were unremarkable and the etiology remained unclear. ${ }^{15}$ Unfortunately, focal intracranial lesions similar to those illustrated in the case may never be be confirmed in most of the COVID-19 cases.

One of the case series studies reported that sporadic epileptiform discharges (interictal changes) tend to happen more frequently in COVID-19 positive patients $(40.9 \%)$ than in a COVID-19 negative control group $(16.7 \%) .{ }^{5}$ Even after excluding patients with a prior history of seizure, interictal changes are still more common in COVID-19 positive patients than in the control group. The COVID-19-negative group included ICU patients with a similar encephalopathy, therefore eliminating the explanation that the decreased seizure threshold is due to metabolic derangement or sepsis. Bilateral frontal symmetrical or asymmetrical sharp waves are the major patterns of sporadic epileptiform discharges in this study, which correlated with the hypothesis that COVID-19 enters CNS through the olfactory pathway. ${ }^{28}$ This bifrontal epileptic origin was also reported in two independent case reports. ${ }^{8,14}$ Although no statistical significance was achieved due to the limited sample size, this study offers the possibility of a unique mechanism of CNS involvement with this virus.

\section{ConCLUSION}

Acute encephalopathy is common in the context of COVID-19, and the etiology is usually multifactorial. EEG studies in COVID-19 patients are rarely done or reported. Limitations of all the studies are apparent and include small sample sizes and a lack of CSF studies and MRIs in most of the patients. Although helpful information can be obtained from EEG studies in COVID-19 patients, it is important to weigh the value of the study in diagnosis and management of the patient against the possible risk of virus transmission to the EEG technician.
Article citation: Pan J, Khan S, Thakolwiboon S, Chi D. Electroencephalographic abnormalities in COVID-19-related encephalopathies: A systematic review. The Southwest Respiratory and Critical Care Chronicles 2020;8(35):36-41

From: Department of Neurology (JP, ST, DC) and the School of Medicine (SK), Texas Tech University Health Sciences Center, Lubbock, Texas

Submitted: $7 / 10 / 2020$

Accepted: $7 / 13 / 2020$

Reviewer: Kenneth Nugent MD

Conflicts of interest: none

This work is licensed under a Creative Commons Attribution-ShareAlike 4.0 International License.

\section{REFERENCES}

1. Zaim S, Chong JH, Sankaranarayanan V, et al. COVID-19 and multiorgan response. Current Problems in Cardiology 2020; 45:100618.

2. Mao L, Jin H, Wang M, et al. Neurologic manifestations of hospitalized patients with coronavirus disease 2019 in Wuhan, china. JAMA Neurology 2020;77(6):1-9.

3. Varatharaj A, Thomas N, Ellul MA, et al. Neurological and neuropsychiatric complications of COVID-19 in 153 patients: A UK-wide surveillance study. The Lancet. Psychiatry 2020;S2215-0366(20)30287-X.

4. Cecchetti G, Vabanesi M, Chieffo R, et al. Cerebral involvement in COVID-19 is associated with metabolic and coagulation derangements: An EEG study. J Neurology 2020;1-5; forthcoming. doi: 10.1007/s00415-020-09958-2

5. Galanopoulou AS, Ferastraoaru V, Correa DJ, et al. EEg findings in acutely ill patients investigated for sars-cov-2/ COVID-19: A small case series preliminary report. Epilepsia open 2020;5:314-324.

6. Vespignani H, Colas D, Lavin BS, et al. Report of EEG finding on critically ill patients with COVID-19. Annals Neurology 2020; forthcoming. https://doi: 10.1002/ana.25814

7. Scullen T, Keen J, Mathkour M, et al.Coronavirus 2019 COVID-19-associated encephalopathies and cerebrovascular disease: The New Orleans experience. World Neurosurgery 2020;S1878-8750(20)31163-3.

8. Balloy G, Mahe PJ, Leclair-Visonneau L, et al. Non-lesional status epilepticus in a patient with coronavirus disease 2019. Clinical neurophysiology: official journal of the International Federation Clin Neurophysiology 2020;131(8):2059-2061. 
9. Bernard-Valnet R, Pizzarotti B, Anichini A, et al. Two patients with acute meningoencephalitis concomitant with SARS-CoV-2 infection. Euro J Neurology 2020; forthcoming. https://doi: 10.1111/ene.14298

10. De Stefano P, Nencha U, De Stefano L, et al. Focal EEG changes indicating critical illness associated cerebral microbleeds in a COVID-19 patient. Clinical Neurophysiology Practice 2020;5:125-129.

11. Dugue R, Cay-Martinez KC, Thakur KT, et al. Neurologic manifestations in an infant with COVID-19. Neurology 2020; 94:1100-1102.

12. Duong L, Xu P, Liu A. Meningoencephalitis without respiratory failure in a young female patient with COVID-19 infection in downtown Los Angeles, early April 2020. Brain, Behavior, and Immunity 2020;87:33.

13. Filatov A, Sharma P, Hindi F, et al. Neurological complications of coronavirus disease (COVID-19): Encephalopathy. Cureus 2020;12:e7352.

14. Flamand M, Perron A, Buron $Y$, et al. Pay more attention to EEG in COVID-19 pandemic. Clinical Neurophysiology: 2020;131(8):2062-2064.

15. Le Guennec L, Devianne J, Jalin L, et al. Orbitofrontal involvement in a neurocovid-19 patient. Epilepsia 2020; forthcoming. https://doi.org/10.1111/epi.16612

16. Pilotto A, Odolini S, Masciocchi S, et al. Steroid-responsive encephalitis in coronavirus disease 2019. Annals Neurology 2020; forthcoming. https://doi.org/10.1002/ana.25783

17. Somani S, Pati S, Gaston T, et al. De novo status epilepticus in patients with COVID-19. Annals Clinical Translational Neurology 2020; forthcoming. https://doi.org/10.1002/acn3.510 71

18. Vollono C, Rollo E, Romozzi M, et al. Focal status epilepticus as unique clinical feature of COVID-19: A case report. Seizure 2020;78:109-112.
19. Assenza G, Lanzone J, Ricci L, et al. Electroencephalography at the time of COVID-19 pandemic in italy. Neurological Sciences 2020; forthcoming. https://doi: 10.1007/s10072020-04546-8

20. Faigle R, Sutter R, Kaplan PW. Electroencephalography of encephalopathy in patients with endocrine and metabolic disorders. J Clin Neurophysiology 2013;30:505-516.

21. Bauer G, Trinka E, Kaplan PW. Eeg patterns in hypoxic encephalopathies (post-cardiac arrest syndrome): Fluctuations, transitions, and reactions. J Clin Neurophysiology 2013; 30:477-489.

22. Andraus ME, Andraus CF, Alves-Leon SV. Periodic EEG patterns: Importance of their recognition and clinical significance. Arquivos de neuro-psiquiatria 2012;70:145-151.

23. Bauerschmidt A, Rubinos C, Claassen J. Approach to managing periodic discharges. J Clin Neurophysiology 2018;35:309-313.

24. Garg RK, Sharma PK, Kumar N, et al. Subacute sclerosing panencephalitis in older adulthood. Tremor and other hyperkinetic movements 2019;9:10.7916/tohm.v0.719

25. Xu J, Zhong S, Liu J, et al. Detection of severe acute respiratory syndrome coronavirus in the brain: Potential role of the chemokine mig in pathogenesis. Clinical Infectious Dis 2005;41:1089-1096.

26. Moriguchi T, Harii N, Goto J, et al. A first case of meningitis/ encephalitis associated with SARS-Coronavirus-2. International J Infectious Dis 2020;94:55-58.

27. Ghannam M, Alshaer Q, Al-Chalabi M, et al. Neurological involvement of coronavirus disease 2019: A systematic review. J Neurology 2020;1-19; forthcoming. doi: 10.1007/ s00415-020-09990-2

28. DosSantos MF, Devalle S, Aran V, et al. Neuromechanisms of SARS-CoV-2: A review. Frontiers in Neuroanatomy 2020; $14: 37$. 